\title{
Embryonic Artery
}

National Cancer Institute

\section{Source}

National Cancer Institute. Embryonic Artery. NCI Thesaurus. Code C34145.

Any artery occurring during embryonic development. 